\title{
Efektivitas Kelembagaan Pemerintah dalam Integrasi Pola Pengelolaan Sumber Daya Air dalam Rencana Tata Ruang Wilayah (Studi Kasus: Provinsi Jawa Tengah)
}

\author{
Silviani Junita ${ }^{1}$ \\ Direktorat Jenderal Sumber Daya Air \\ Imam Buchori \\ Jurusan Perencanaan Wilayah dan Kota \\ Universitas Diponegoro, Semarang, Indonesia

$\begin{array}{ll}\text { Artikel Masuk } & : \text { 11 Januari } 2016 \\ \text { Artikel Diterima } & : 28 \text { Maret } 2016 \\ \text { Tersedia Online } & \text { : } 30 \text { April } 2016\end{array}$

Kementerian Pekerjaan Umum, Jakarta, Indonesia

\begin{abstract}
Abstrak: Efektivitas integrasi pola pengelolaan sumber daya air ke dalam Rencana Tata Ruang Wilayah (RTRW) dapat dicapai apabila terdapat kerjasama antar lintas sektor yang harmonis. Penelitian bertujuan untuk menganalisis peran dan pola koordinasi lembaga lintas sektoral terkait perencanaan dan pengelolaan air dalam RTRW. Penelitian menggunakan pendekatan kualitatif melalui analisis terhadap peran dan kordinasi kelembagaan lintas sektoral serta analisis efektivitas dalam keberhasilan integrasi pola pengelolaan sumber daya air dalam RTRW. Temuan penelitian menunjukkan bahwa integrasi pola pengelolaan sumber daya air dalam rencana tata ruang masih kurang efektif yang ditunjukkan oleh kurang efektifnya kelembagaan pemerintah dalam menjalankan peran sebagai pembuat kebijakan dan kurangnya koordinasi antar lembaga terkait mengenai muatan dari pola pengelolaan sumber daya air yang wajib masuk dalam rencana tata ruang. Untuk itu, diperlukan wadah koordinasi untuk menjembatani kepentingan sumber daya air dan tata ruang.
\end{abstract}

Kata kunci: kelembagaan pemerintah, integrasi pengelolaan sumber daya air, RTRW

\begin{abstract}
The effectiveness of integrating water resources management into spatial planning $(R T R W)$ can be achieved if there is a harmonious coordination between central government and local government. This research aims to analyze the role of and coordinating pattern of inter-sectoral institutions related to water resource planning and management in spatial planning. The research is conducted by using qualitative approach through the analysis of the role of and coordination in inter-sectoral institutions and the effectiveness of the successful integration of water resources management in spatial planning. The findings show that the integration of water resources management pattern in the spatial planning is ineffective indicated by the ineffectiveness of government institution as the policy maker and the lack of
\end{abstract}

\footnotetext{
${ }^{1}$ Korespondensi Penulis: Direktorat Jenderal Sumber Daya Air, Kementerian Pekerjaan Umum, Jakarta, Indonesia email: silvia_junita@yahoo.com
} 


\section{Efektivitas Kelembagaan Pemerintah dalam Integrasi Pola Pengelolaan Sumber Daya Air ...}

coordination between institutions regarding the content of water resource management in spatial planning. Therefore, it is necessary to make a coordination forum to accommodate the interests of water resources and spatial planning.

Keywords: government institution, integration of water resources management, spatial planning

\section{Pendahuluan}

Saat ini penyelenggaraan pembangunan di Indonesia berkembang pesat. Pembangunan nasional yang cepat dan peningkatan jumlah penduduk yang memanfaatkan sumber daya lahan telah menyebabkan masalah sosial dan lingkungan yang serius di Indonesia. Untuk itu, dibutuhkan upaya terpadu untuk mengatasi dan pengelolaan sumber daya yang tepat (Pawitan \& Haryani, 2011). Seiring dengan hal tersebut, berbagai permasalahan muncul dan tidak terkecuali dalam pengelolaan sumber daya air.

Permasalahan sumber daya air menyangkut masalah kuantitas, kualitas, dan kelembagaan. Persoalan air bukan sekedar persoalan kualitas saja tetapi persoalan kuantitas dan kontinuitas (Budihardjo, 1996; Yuwono, Sinukaban, Murtilaksono, \& Sanim 2011). Serupa dengan Halimatusadiah, Dharmawan, dan Mardiana (2012) yang mengungkapkan bahwa kerusakan Daerah Aliran Sungai (DAS) yang terjadi saat ini dipercepat oleh peningkatan pemanfaatan sumber daya alam sebagai akibat dari pertambahan penduduk, konflik kepentingan, kurangnya keterpaduan antar sektor, dan antara wilayah hulu-tengah-hilir. Hal yang perlu dipahami bahwa permasalahan air bukan merupakan permasalahan yang berdiri sendiri namun ada kaitannya dengan isu perencanaan guna lahan (Mitchell, 2005). Lahan dan sumber daya tidak hanya menyangkut keberadaan sumber daya yang bersangkutan namun juga mengenai keberlanjutan ekosistem, aktivitas manusia, dan kerjasama antar stakeholder yang menyangkut kebijakan kontrol pemanfaatan (Garmendia, Mariel, Tamanyo, Aizpuru, \& Zabaleta, 2012).

Pola pengelolaan sumber daya air merupakan sistem perencanaan, pelaksanaan dan pengawasan yang membutuhkan implementasi melalui kelembagaan yang terkait dan relevan. Grigg (1996) mendefinisikan pengelolaan sumber daya air sebagai aplikasi dari cara struktural dan nonstruktural untuk mengendalikan sistem sumber daya air alam dan buatan manusia untuk kepentingan/ manfaat manusia dan tujuan lingkungan. Pengelolaan sumber daya air terpadu (integrated water resources management) adalah sebuah proses yang mempromosikan koodinasi pengembangan dan pengelolaan air, tanah dan sumbersumber terkait dengan tujuan untuk mengoptimalkan resultan ekonomis dan kesejahteraan sosial dalamperilaku yang cocok tanpa mengganggu kestabilan dari ekosistem-ekosistem penting Global Water Pertnership Technical Advisory Commitee (dalam Kodoatie \& Sjarief, 2005). Untuk itu, untuk mencapai pengelolaan sumber daya air berkelanjutan diperlukan integrasi antar stakeholder terkait (Juwana, Muttil, \& Perera, 2012). Dalam mengelola sumber daya air diperlukan pendekatan yang menyeluruh dan sistematis dalam konteks perencanaan guna lahan untuk menjamin keberlanjutan lingkungan (Moss, 2004; Mitchell, 2005; Fidelis \& Roebeling, 2014) dan mengatur kelembagaan perencanaan melalui peran dan praktik kebijakan baru (Wiering \& Immink, 2006). Di dalamnya perlu ada mekanisme koordinasi antar lembaga yang adaptif dan memiliki kekuatan hukum (Santosa, 2006).

Efektivitas integrasi pola pengelolaan sumber daya air ke dalam Rencana Tata Ruang Wilayah (RTRW) akan dapat dicapai apabila terdapat kerjasama antar lintas sektor yang harmonis. Koordinasi, integrasi, sinkronisasi, dan implikasi dalam kelembagaan pengelolaan sumber daya air dan kelembagaan tata ruang perlu dilakukan agar keberlangsungan sumber daya air dapat terakomodir dalam Rencana Tata Ruang Wilayah 
Provinsi Jawa Tengah. Ini dikarenakan pemerintah mempunyai tanggung jawab dan wewenang untuk mengatur perencanaan tata ruang agar daya dukung lingkungan tetap terjaga (Kodoatie \& Sjarief, 2010). Dalam konteks penataan ruang, kelembagaan memiliki dua aspek penting, meliputi aspek pengaturan, hukum dan kebijakan serta lembagalembaga yang bekerjasama untuk mencapai tujuan penataan ruang.

Upaya mengevaluasi jalannya suatu organisasi dapat dilakukan melalui konsep efektivitas. Menurut Stokke (dalam Nielsen, Frederiksen, Saarikoski, Rytkonen, \& Pedersen, 2013) efektivitas organisasi dicapai melalui tiga mekanisme, yaitu biaya yang akan saling mempengaruhi antar organisasi yang menimbulkan koordinasi, norma atau regulasi yang berlaku dalam orgnanisasi, dan kebijakan yang mempengaruhi tujuan dari organisasi tersebut. Interkasi kelembagaan mengacu pada saling ketergantungannya kelembagaan pemerintah dalam pengaturan sehingga efektivas kelembagaan dipengaruhi oleh koordinasi anatr kelembagaan tersebut (Nielsen et al., 2013). Koordinasi berperan penting dalam merumuskan pembagian tugas, wewenang, dan tanggung jawab dalam organisasi, sekaligus melahirkan jaringan hubungan kerja yang diperlukan oleh organisasi. Desentralisasi secara signifikan merubah pola investasi di daerah, hal ini terlihat jelas dalam bidang pendidikan, air dan sanitasi, pengelolaan air, pertanian, dan pembangunan daerah (Faguet, 2004).

Peran penataan ruang dalam pengelolaan sumber daya air adalah untuk menjamin ketersediaan air, baik kualitas maupun kuantitas, untuk masa kini dan masa mendatang melalui pengelolaan kawasan konservasi dan pengendalian kualitas air. Namun demikian, tantangan yang akan dihadapi dalam integrasi pengelolaan sumber daya air dengan penataan ruang adalah kebutuhan untuk memperhitungkan variabilitas spasial sumber daya air, infrastruktur yang ada, konflik kepentingan yang berbeda, prioritas, kebijakan, dan instrumen perencanaan yang perlu ditangani oleh para pembuat keputusan dan lembaga pemerintahan. Berdasarkan hal tersebut, maka perlu ada komunikasi dan kepedulian yang efektif antar kelembagaan dalam pengelolaan sumber air yang terpadu dan berkelanjutan. Peran dan koordinasi antar lembaga pengelolaan sumber daya air dengan lembaga tata ruang sangat penting demi terwujudnya pengendalian sumber daya air yang tertuang dalam rencana tata ruang. Oleh karena itu, perlu adanya kajian terkait efektivitas kelembagaan sumber daya air dengan lembaga tata ruang. Penelitian bertujuan untuk menganalisis peran dan pola koodinasi lembaga lintas sektoral terkait perencanaan dan pengelolaan sumber daya air dalam Rencana Tata Ruang Wilayah (RTRW). Melalui penelitian diharapkan akan menjadi masukkan pemerintah mengenai kekurangan yang muncul dan hal yang perlu dilakukan dalam pengelolaan sumber daya air dalam konteks RTRW.

\section{Metode Penelitian}

Penelitian menggunakan metode penelitian kuantitatif dengan pendekatan positifivistik yang bersifat deduktif. Menurut Sugiyono (2008) proses penelitian bersifat deduktif dimana untuk menjawab rumusan masalah digunakan konsep atau teori. Berdasarkan pendekaan tersebut penelitian ini didasarkan pada fakta yang terjadi di lapangan yang kemudian dilakukan kajian berupa efektivitas kelembagaan pemerintah dalam mengintegrasikan pola pengelolaan sumber daya air dalam rencana tata ruang wilayah di Provinsi Jawa Tengah.

Metode pengumpulan data yang digunakan adalah metode pengumpulan data primer dan data sekunder. Metode pengumpulan data primer dilakukan dengan observasi lapangan, kuesioner, wawancara. Observasi lapangan berguna untuk memperoleh gambaran mengenai koordinasi lembaga sumber daya air dan tata ruang terkait integrasi pola pengelolaan sumber daya air dan melihat kewenangan dalam kaitan integrasi tersebut. 


\section{Efektivitas Kelembagaan Pemerintah dalam Integrasi Pola Pengelolaan Sumber Daya Air ...}

Wawancara dan kuesioner dilakukan untuk mengetahui persepsi responden terkait integrasi pola pengelolaan sumber daya air dalam RTRW. Kuesioner dan wawancara diberikan kepada pihak yang terkait erat dengan keberhasilan program integrasi pola pengelolaan sumber daya air dalam rencana tata ruang, meliputi Ditjen Sumber Daya Air dan Ditjen Penataan Ruang Kementerian PU sebanyak 10 responden, Bappeda Provinsi Jawa Tengah sebanyak 6 orang, Dinas Cipta Karya dan Tata Ruang Provinsi Jawa Tengah sebanyak 4 responden, dan Dinas PSDA Provinsi Jawa Tengah sebanyak 10 responden sehingga total kuesioner sebanyak 30 responden. Metode pengumpulan data sekunder dilakukan dengan kajian dokumen serta kajian pustaka dari buku, Undang-Undang, jurnal, tesis, serta artikel internet. Adapun analisis-analisis yang dilakukan dalam penelitian ini adalah:

1. Analisis Kebijakan

Analisis meliputi kajian terkait identifikasi kelembagaan penataan ruang serta identifikasi kelembagaan pengelolaan sumber daya air oleh Pemerintah Pusat maupun Pemerintah Daerah di Provinsi Jawa Tengah sebagai pihak yang berperan penting dalam kelembagaan pemerintah.

2. Analisis Daya Dukung Kelembagaan

Tahapan analisis ini melakukan kajian mengenai peranan kelembagaan pemerintah dalam koordinasi lintas sektoral terhadap integrasi pola pengelolaan sumber daya air dalam rencana tata ruang wilayah serta mengkaji efektivitas kelembagaan pemerintah.

\section{Hasil dan Pembahasan}

\section{Identifikasi Kelembagaan Pemerintah Terkait Integrasi Pola Pengelolaan Sumber Daya Air dalam Rencana Tata Ruang Wilayah di Provinsi Jawa Tengah}

Kebijakan tentang pengelolaan sumber daya air harus mengarahkan pada aspekaspek konservasi, perlindungan dan pemanfaatan sumber daya air. Secara lebih spesifik untuk Indonesia maka kebijakan pengelolaan sumber daya air sesuai dengan UndangUndang sumber daya air adalah konservasi sumber daya air, pendayagunaan sumber daya air dan pengendalian daya rusak air. Oleh karena itu, kebijakan yang diciptakan harus mengarah kepada tujuan dalam ketiga aspek utama tersebut.

Kebijakan di luar kebijakan sumber daya air yang terkait dapat memberikan dampak terhadap pengelolaan sumber daya air. Kebijakan tersebut di antaranya kebijakan tentang tata ruang, kebijakan tentang lingkungan, kebijakan tentang otonomi daerah serta kebijakan tentang infrastruktur. Alat untuk mengkoordinasikan kebijakan di luar sumber daya air dan kebijakan tentang sumber daya air antara lain: koordinasi antar kementerian, badan tertinggi untuk pengelolaan sumber daya air (nasional), badan koordinasi tingkat wilayah (provinsi dan kabupaten/kota), badan koordinasi tingkat daerah aliran sungai, tim koordinasi di tingkat lokal atau regional

Kebijakan tentang sumber daya air diterjemahkan dalam aspek hukum melalui peraturan perundang-undangan tentang sumber daya air yang dipakai sebagai acuan hukum. Dalam pengelolaan sumber daya air acuan hukum yang digunakan adalah UndangUndang Nomor 7 Tahun 2004 tentang Sumber Daya Air. Kebijakan lainnya sebagai peraturan pelaksana Undang-Undang tersebut terdapat Peraturan Pemerintah Nomor 42 Tahun 2008 tentang Pengelolaan Sumber Daya Air. Kedua dasar kebijakan tersebut akan digunakan sebagai alat analisis untuk megidentifikasi kelembagaan pengelolaan sumber daya air sebagaimana tersaji di Gambar 1.

Berdasarkan skema keterkaitan Gambar 1, peran kordinasi yang efektif merupakan faktor penentu terkait dengan ketersedian sumber daya air. Sebagian besar ketentuan tersebut diatur dalam beberapa peraturan perundang-undangan. Undang-Undang terkait di 
atas baik yang mengatur tentang sumber daya air ataupun tata ruang bisa digunakan sebagai acuan untuk menganalisis kelembagaan-kelembagaan yang terlibat di dalamnya.

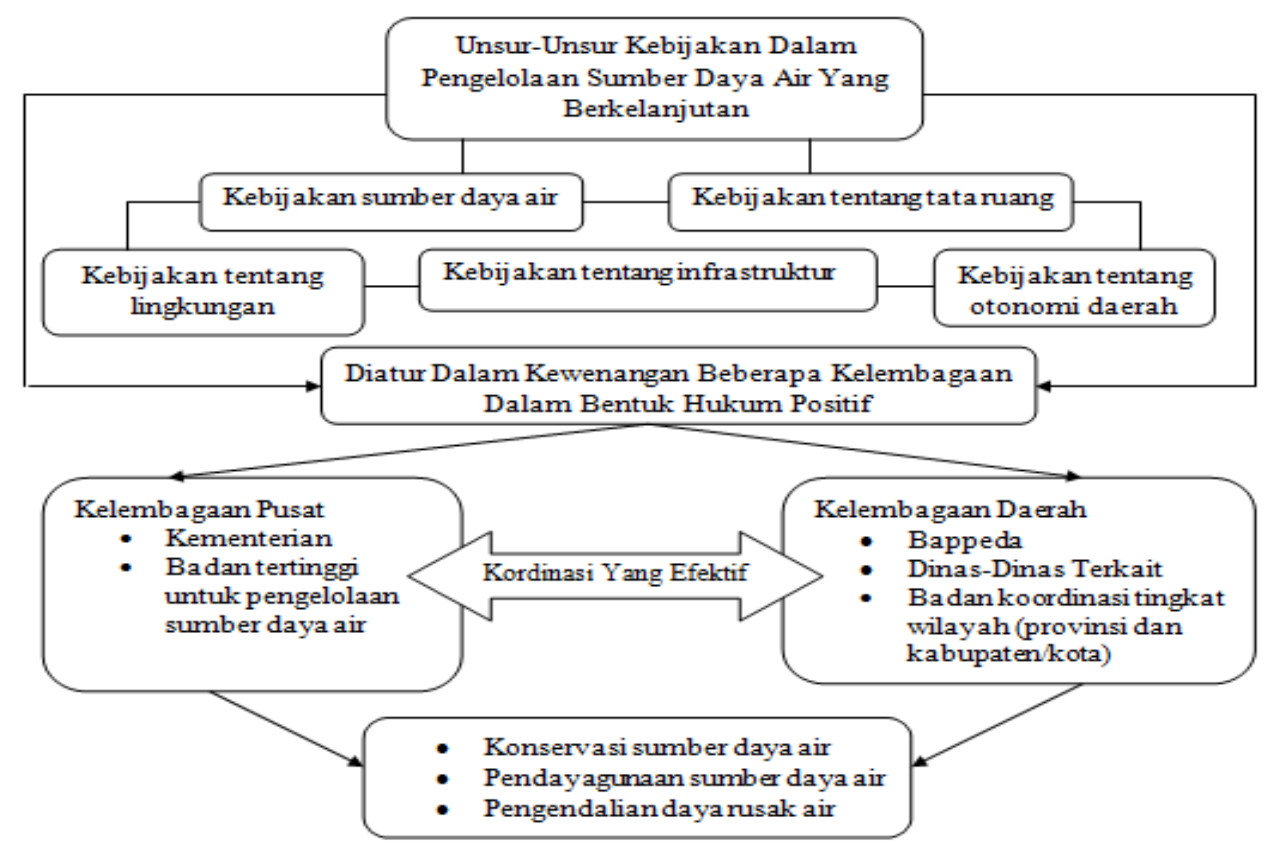

Gambar 1. Skema Keterkaitan Antara Kebijakan dan Kelembagaan Dalam Penyediaan Sumber Daya Air yang Berkelanjutan

\section{Identifikasi Kelembagaan Pengelolaan Sumber Daya Air di Provinsi Jawa Tengah}

Kelembagaan sumber daya air luas cakupannya dilihat dari berbagai aspek pengelolaannya karena banyak unsur pemerintah maupun nonpemerintah yang terlibat di dalamnya. Berdasarkan hasil analisis maka secara garis besar kelembagaan dalam pengelolaan sumber daya air untuk mewujudkan ketersedian sumber daya air yang berkelanjutan digambarkan dalam struktur organisasi pada Gambar 2. Dalam struktur tersebut terlihat bahwa kordinasi yang efektif antara setiap kelembagaan baik di tingkat pusat maupun daerah merupakan kunci utama dalam pencapaian keefektivan tujuan yang ingin dicapai. Selain itu, dalam struktur kelembagaan pengelolaan sumber daya air selain terdapat kelembagaan yang merupakan kelembagaan dari unsur pemerintah juga terdapat kelembagaan yang bersifat nonstruktural. Kelembagaan yang merupakan kelembagaan bersifat nonstruktural adalah Dewan Sumber Daya Air Nasional, yaitu wadah koordinasi yang dibentuk untuk melaksanakan ketentuan Pasal 86 ayat (4) UU Nomor 7 Tahun 2004 tentang Sumber Daya Air dan mengintegrasikan kepentingan berbagai sektor, wilayah, serta para pemilik kepentingan dalam pengelolaan sumber daya air melalui proses koordinasi. 


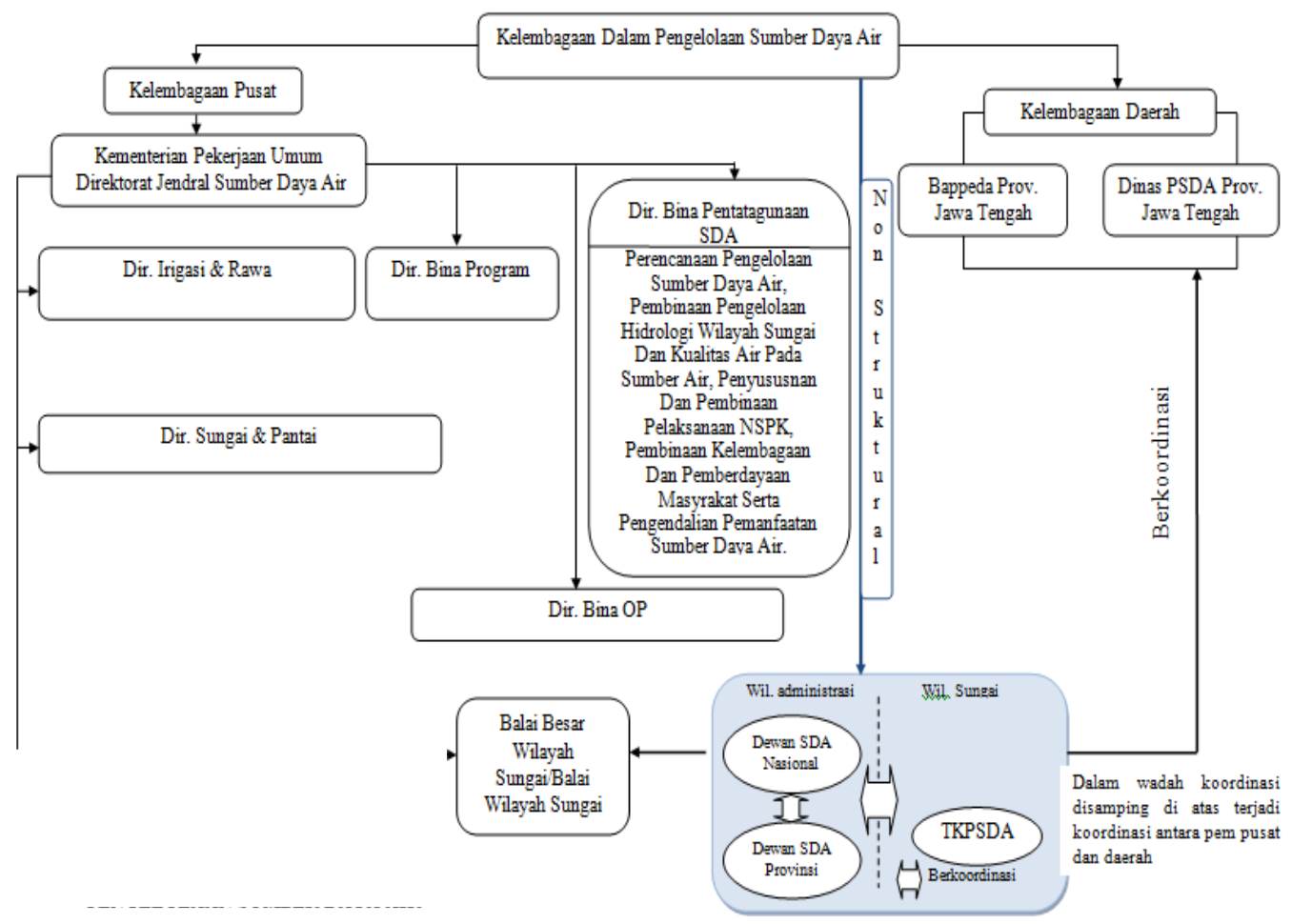

Gambar 2. Struktur Kelembagaan Pengelolaan Sumber Daya Air

\section{Identifikasi Kelembagaan Penataan Ruang di Provinsi Jawa Tengah}

Semenjak diberlakukannya UU Nomor 26 Tahun 2007 tentang Penataan Ruang, Provinsi Jawa Tengah telah menyusun Peraturan Daerah Nomor 6 Tahun 2010 tentang Rencana Tata Ruang Wilayah Provinsi Jawa Tengah Tahun 2009 s.d. 2029. Selain itu, sebanyak 35 Kabupaten/ Kota di Provinsi Jawa Tengah juga telah memiliki Perda tentang RTRW Kabupaten/ Kota.

Peningkatan koordinasi penataan ruang nasional dan daerah melalui Badan Koordinasi Penataan Ruang Nasional (BKRN) dan Badan Koordinasi Penataan Ruang Daerah (BKPRD) berperan penting. Selain itu, peningkatan koordinasi Penataan Ruang antara Ditjen Penataan Ruang dan Dinas Tata Ruang Provinsi dan Kabupaten/ Kota. Dalam ketentuan perundangan penataan ruang kelembagaan penataan ruang di Provinsi yaitu BKPRD dengan penanggung jawab langsung oleh Gubernur Provinsi Jawa Tengah serta lembaga pemerintah yaitu Badan Perencana Daerah dan Dinas Cipta Karya dan Tata Ruang Provinsi Jawa Tengah. Gambar 3 menyajikan kondisi struktur kelembagaan penataan ruang di Provinsi Jawa Tengah. 


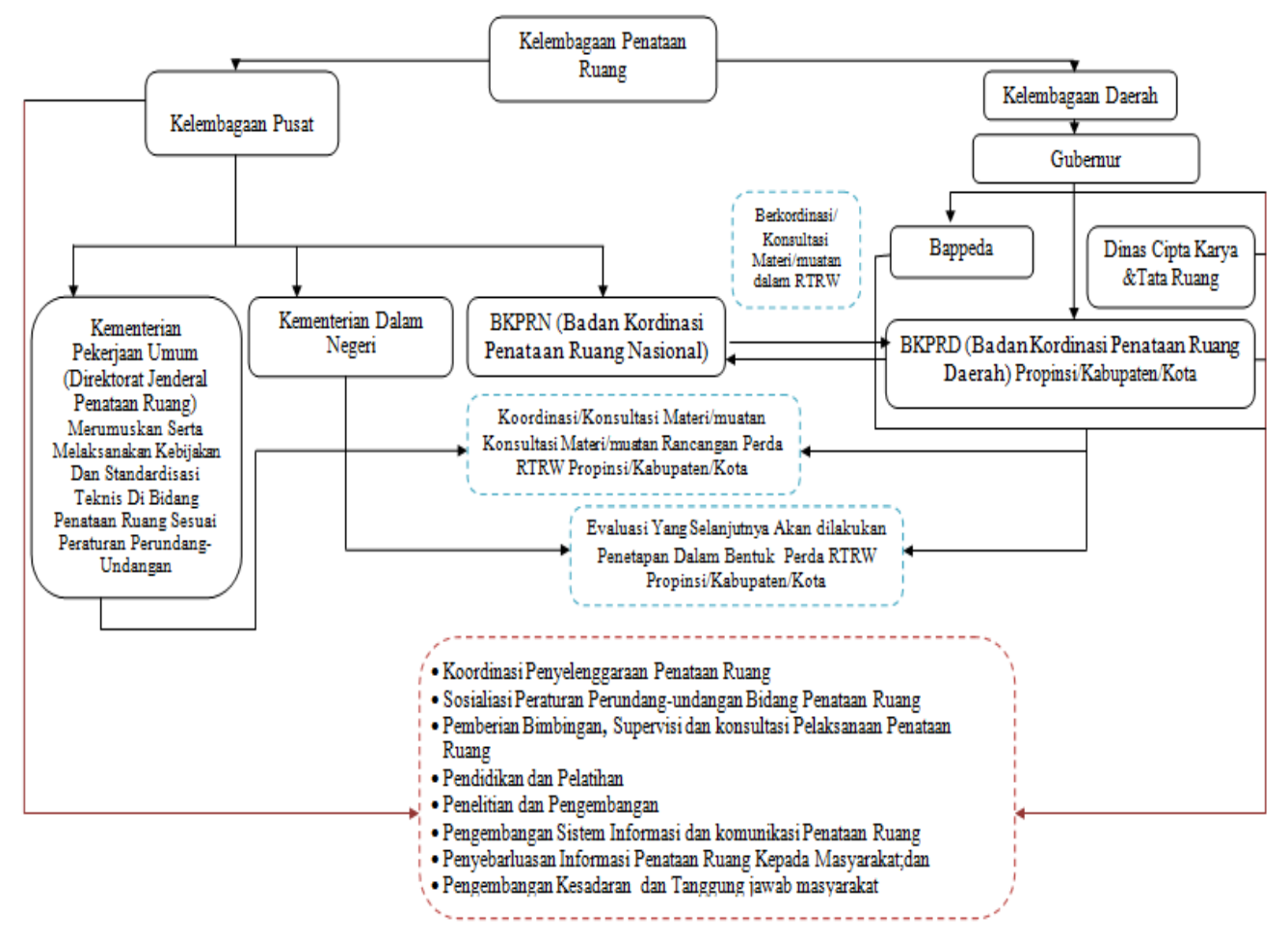

Gambar 3. Struktur Kelembagaan Penataan Ruang

\section{Analisis Daya Dukung Kelembagaan pada Integrasi Pola Pengelolaan Sumber Daya Air dalam Rencana Tata Ruang Wilayah Provinsi Jawa Tengah}

Pengelolaan sumber daya air mencakup kepentingan lintas sektoral dan lintas wilayah yang memerlukan keterpaduan melalui koordinasi dengan mengintegrasikan kepentingan berbagai sektor, wilayah, dan para pemilik kepentingan dalam bidang sumber daya air. Sementara itu, program-program sektor yang diharapkan dapat memberikan kontribusi langsung maupun tidak langsung terhadap upaya konservasi sumber daya air nampaknya masih berjalan sendiri-sendiri sehingga hasil kerja yang diharapkan kurang bisa bersinergi dan tidak optimal karena lemahnya koordinasi antar sektor serta ketiadaan rencana induk yang diharapkan dapat menjadi pemandu sekaligus bingkai pengikat dalam penyusunan program dan kegiatan antar sektor dan antar daerah.

Koordinasi yang terjadi antara lembaga pengelolaan sumber daya air dengan lembaga penataan ruang terjadi pada unsur kebijakan. Pengelolaan sumber daya air saling sinkron dengan perencanaan tata ruang. Namun, masih terdapat kendala dalam penyamaan pandangan terkait peraturan yang menjadi acuan dalam penyusunan pola pengelolaan sumber daya air ataupun rencana tata ruang. Penyusunan rencana tata ruang provinsi haruslah mengacu kepada pola pengelolaan sumber daya air agar terjadi keterpaduan dengan rencana pengembangan wilayah. Gambar 4 menyajikan tentang permasalahan koordinasi lembaga sumber daya air dan tata ruang.

Gambar 4 memperlihatkan permasalahan koordinasi yang terjadi di dalam lembaga sumber daya air dan tata ruang. Permasalahan yang terjadi antara lain koordinasi yang kurang baik antara dinas pengelolaan sumber daya air dan dinas cipta karya dan tata ruang, lemahnya koordinasi antar kedua instansi tersebut disebabkan mereka mempunyai bidang masing-masing yang pekerjaannya berbeda. 


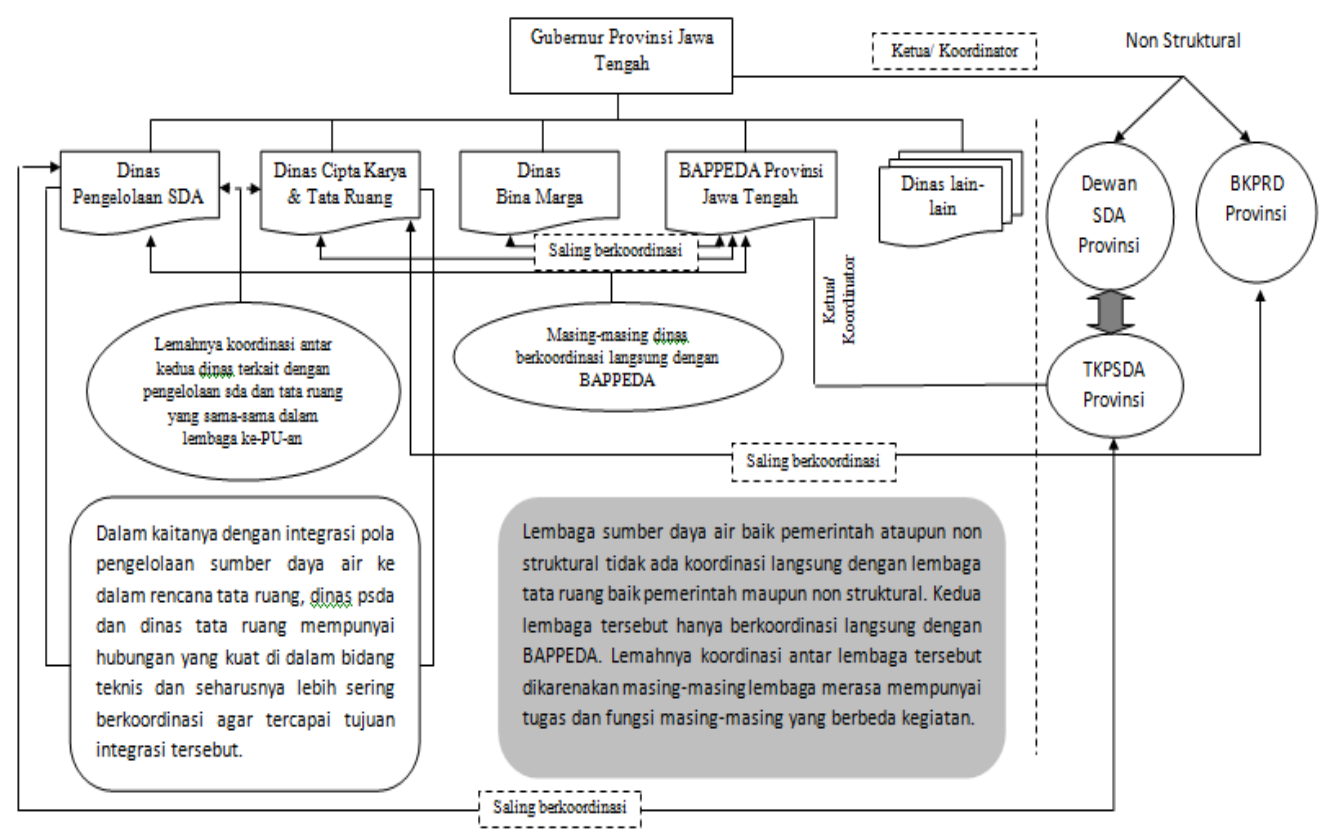

Gambar 4. Permasalahan Koordinasi Lembaga Sumber Daya Air dan Tata Ruang

Masalah yang menjadi penting dalam integrasi pola pengelolaan sumber daya air dalam rencana tata ruang adalah muatan dari Undang-Undang yang menjadi acuan masing-masing bidang baik sumber daya air maupun tata ruang yang berbeda. Banyak perbedaan substansi dalam Undang-Undang Nomor 7 Tahun 2004 tentang Sumber Daya Air dengan Undang-Undang Nomor 26 Tahun 2007 tentang Penataan Ruang. Berikut adalah perbedaan substantif antara kedua undang - undang tersebut:

- UU Penataan Ruang tidak menyebutkan Wilayah Sungai namun hanya Daerah Aliran Sungai (DAS), padahal Indonesia sendiri dibagi menjadi 133 Wilayah Sungai (Peraturan Menteri Pekerjaan Umum Nomor 11 A Tahun 2006) menurut tinjauan batas hidrologis dan 33 Provinsi untuk tinjauan administrasi;

- UU Penataan Ruang menyebutkan bahwa dalam penatagunaan air, dikembangkan 'Pola Pengelolaan Daerah Aliran Sungai (DAS)' bukan 'Pola Pengelolaan Sumber Daya Air Wilayah Sungai' seperti yang diamanatkan UU Sumber Daya Air;

- Perlu klarifikasi, kesepahaman dan kesepakatan tentang pengertian 'Pola Pengelolaan Sumber Daya Air Wilayah Sungai menurut UU Sumber Daya Air' dan 'Pola Pengelolaan Daerah Aliran Sungai (DAS) menurut UU Penataan Ruang'.

Perbedaan materi dalam kedua Undang-Undang tersebut membuat sulitnya untuk menselaraskan tujuan dari kedua Undang-Undang tersebut. Hal ini jugalah yang menjadi penyebab hingga saat ini belum tecapainya integrasi pola pengelolaan sumber daya air dalam rencana tata ruang. Dalam pelaksanaan penataan ruang terdapat siklus penataan ruang yaitu perencanaan tata ruang, pemanfaatan ruang serta pengendalian pemanfaatan ruang. Sedangkan dalam pengelolaan sumber daya air pelaksanaan lebih secara teknis dan lagi-lagi mempunyai perbedaan substansi satu sama lain dimana sumber daya air memiliki istilah 'Pengelolaan' sedangkan tata ruang memiliki istilah 'Penataan'. Tabel I berikut menunjukkan perbedaan substantif dari kedua Undang-Undang tersebut. 
Tabel 1. Substansi Sumber Daya Air dan Tata Ruang

\begin{tabular}{|c|c|}
\hline Undang - Undang Sumber Daya Air & Undang - Undang Penataan Ruang \\
\hline Pengelolaan Sumber Daya Air & Penyelenggaraan Penataan Ruang \\
\hline 1. Pola pengelolaan sda & 1. Pengaturan penataan ruang \\
\hline 2. Rencana pengelolaan sda & 2. Pembinaan penataan ruang \\
\hline 3. Studi Kelayakan & 3. Pengawasan penataan ruang \\
\hline 4. Program pengelolaan sda & 4. Pelaksanaan penataan ruang; \\
\hline 5. Penyusunan rencana kegiatan pengelolaan sda & - Perencanaan tata ruang \\
\hline 6. Rencana detail - rencana pelaksanaan & - Pemanfaatan ruang \\
\hline konstruksi \& OP & - Pengendalian pemanfaatan ruang \\
\hline 7. Pelaksanaan konstruksi & \\
\hline 8. Pelaksanaan OP & \\
\hline
\end{tabular}

Berdasarkan Tabel 1 terdapat perbedaan dalam istilah sumber daya air dan tata ruang. Diperlukan integrasi dalam pengelolaan sumber daya air serta tata ruang agar tercapai kesepahaman dalam mencapai tujuan keberlanjutan sumber daya alam. Pengelolaan dan Penataan mempunyai makna yang berbeda sehingga pada pengelolaan sumber daya air dan penataan ruang diperlukan persamaan bahasa agar bisa tercipta kesatuan antara sumber daya air dan tata ruang. Persamaan yang perlu disepakati bersama dalam hal penyatuan istilah dalam Undang-Undang sumber daya air maupun tata ruang.

\section{Efektivitas Peran dan Koordinasi Kelembagaan dalam Integrasi Pola Pengelolaan Sumber Daya Air}

Wadah koordinasi dalam memadukan perencanaan daerah dengan pola pengelolaan sumber daya air, yaitu Dewan Sumber Daya Air Daerah yang diketuai oleh Gubernur Provinsi Jawa Tengah dan Tim Koordinasi Pengelolaan Sumber Daya Air (TKPSDA) dimana Badan Perencanaan Daerah (BAPPEDA) Provinsi Jawa Tengah merupakan ketua dari tim tersebut. Secara tidak langsung lembaga pengelolaan sumber daya air dapat langsung berkoordinasi di bawah BAPPEDA. Sebagai koordinator perencanaan, BAPPEDA membentuk kelompok kerja yang terdiri dari orang-orang yang kompeten di bidangnya seperti Dinas PSDA.

Pemerintah pusat dan pemerintah daerah harus saling berkoordinasi dalam menyelenggarakan pengelolaan sumber daya air yang berkelanjutan agar sesuai dengan rencana tata ruang. Menurut Nielsen, et al (2013) interkasi kelembagaan mengacu pada saling ketergantungannya kelembagaan pemerintah dalam pengaturan sehingga efektivas kelembagaan dipengaruhi oleh koordinasi antar kelembagaan tersebut. Dalam halnya pengelolaan sumber daya air antara pemerintah pusat dengan pemerintah provinsi perlu terjadinya keterpaduan. Ini dikarenakan pengelolaan sumber daya air berdasarkan wilayah sungai sifatnya lebih kompleks. Wilayah sungai yang melintasi provinsi menjadi tanggung jawab pusat dalam pengelolaannya namun tetap melibatkan pemerintah provinsi.

Dalam pengelolaan sumber daya air agar terpadu dalam rencana tata ruang perlu adanya pola dan rencana pengelolaan wilayah sungai, dimana belum semua daerah memiliki rencana dan pola wilayah sungai. Di Provinsi Jawa Tengah terdapat 5 (lima) wilayah sungai yang menjadi kewenangan pusat dan 2 (dua) wilayah sungai yang menjadi kewenangan daerah. Wadah koordinasi yang terjadi antara pemerintah pusat dan daerah terdapat dalam TKPSDA. Setiap wilayah sungai memiliki TKPSDA masing-masing. Ketua TKPSDA adalah Kepala BAPPEDA Provinsi Jawa Tengah dan Balai Besar Wilayah Sungai/ Balai Wilayah Sungai di masing-masing wilayah sungai menjadi anggotanya. Selain berkoordinasi dalam TKPSDA terdapat wadah koordinasi yang berhubungan antara pemerintah pusat dan pemerintah daerah yaitu dalam Dewan Sumber Daya Air Daerah. 
Lembaga-lembaga tersebut sangat berkaitan erat dengan berhasilnya integrasi pola pengelolaan sumber daya air dalam rencana tata ruang.

Koordinasi antar organisasi pemerintah pusat dan provinsi dengan melibatkan semua organisasi pemerintah terkait dalam perencanaan dan pelaksanaan pembuatan kebijakan diperlukan guna mencapai keberlanjutan pengelolaan sumber daya air, sehingga diperlukan wadah koordinasi dengan melibatkan ketiga lembaga tersebut sebagaimana terlihat di Gambar 5. Hal ini melengkapi pendapat Fidelis \& Roebeling (2014), Juwana et al. (2012), Mitchell (2005), dan Moss (2004) bahwa dalam pengelolaan sumber daya air diperlukan integrasi antar stakeholder yang sistematis, terpadu, dan menyeluruh.

Berdasarkan Gambar 5 bahwa lembaga nonstruktural, yaitu Dewan Sumber Daya Air tersebut masih belum bisa bersinergi dengan Badan Koordinasi Penataan Ruang dalam mengakomodir usulan integrasi pola pengelolaan sumber daya air dalam rencana tata ruang, sehingga dengan pembentukan wadah koordinasi yang terdiri dari tim Dewan Sumber Daya Air maupun tim Badan Koordinasi Penataan Ruang dapat merumuskan kebijakan sebagai pedoman untuk acuan dalam integrasi pola PSDA dalam rencana tata ruang berupa Peraturan Pemerintah.

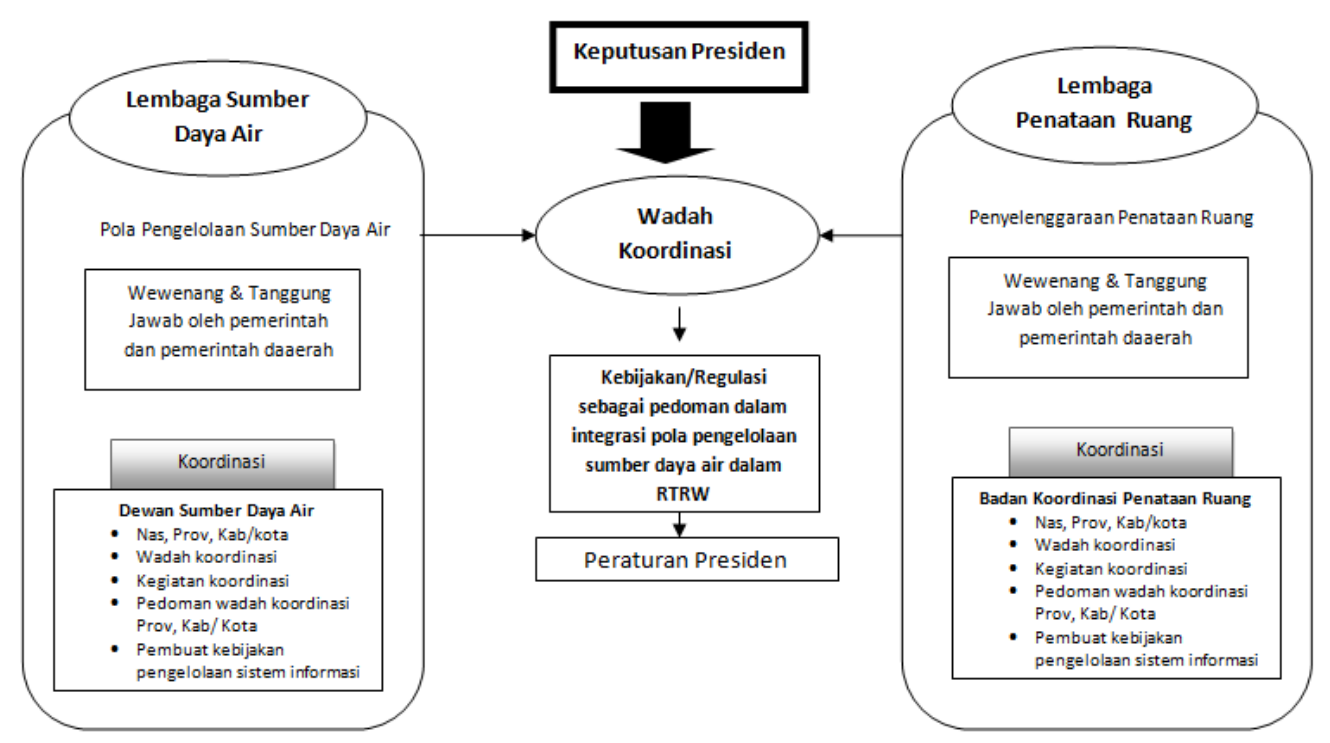

Gambar 5. Skema Pembentukan Wadah Koordinasi Antar Lembaga

\section{Kesimpulan dan Rekomendasi}

\section{Kesimpulan}

Integrasi pola pengelolaan sumber daya air dalam rencana tata ruang masih kurang efektif. Hal ini ditunjukkan oleh kurang efektifnya kelembagaan pemerintah dalam menjalankan peran sebagai pembuat kebijakan dan kurangngnya koordinasi antar lembaga terkait mengenai muatan dari pola pengelolaan sumber daya air yang wajib masuk dalam rencana tata ruang tersebut. Hal ini ditunjukkan oleh kurang efektifnya kelembagaan pemerintah dalam menjalankan peran sebagai pembuat kebijakan dan kurangnya koordinasi antar lembaga terkait mengenai muatan dari pola pengelolaan sumber daya air yang wajib masuk dalam rencana tata ruang tersebut. Perbedaan substansi dari undangundang sumber daya air dan tata ruang merupakan faktor yang cukup berpengaruh dalam ketidakberhasilan pelaksanaan integrasi pola dalam rencana tata ruang. Di samping itu, 
masih terdapat ego sektoral yang menyebabkan efektivitas kelembagaan pemerintah tersebut dalam memadukan pola pengelolaan sumber daya air dalam Rencana Tata Ruang Wilayah (RTRW) di Provinsi Jawa Tengah masih belum dapat tercapai.

\section{Rekomendasi}

Dalam rangka peningkatan peran dan kinerja fungsi koordinasi lembaga lintas sektoral dalam integrasi pola pengelolaan sumber daya air dalam rencana tata ruang wilayah disarankan agar pemerintah baik pusat dan daerah membuat kebijakan tentang muatan pengelolaan sumber daya air yang harus masuk dalam rencana tata ruang wilayah sehingga terjadi kesepakatan dalam penyusunan pola pengelolaan sumber daya air dalam rencana tata ruang. Guna menyusun kebijakan tersebut, diperlukan koordinasi antar organisasi pemerintah pusat dan provinsi dengan melibatkan semua organisasi pemerintah terkait dalam perencanaan dan pelaksanaan pembuatan kebijakan tersebut. Hal ini dapat dilakukan dengan membentuk wadah koordinasi yang melibatkan kedua lembaga terkait sehingga bisa lebih mudah dalam menyusun kebijakan yang dapat menghasilkan pedoman dalam pelaksanaan integrasi pola pengelolaan sumber daya air dalam rencana tata ruang wilayah.

\section{Daftar Pustaka}

Budihardjo, E. (1996). Tata ruang perkotaan. Bandung: Penerbit Alumni.

Faguet, P. (2004). Does decentralization increase government responsiveness to local needs? Evidence from Bolivia. Journal of Public Economics, 88, 867-893. doi:10.1016/S0047-2727(02)00185-8.

Fidelis, T., \& Roebeling, P. (2014). Water resources and land use planning systems in Portugal. Land Use Policy, 39, 84-95. doi:10.1016/j.landusepol.2014.03.010.

Garmendia, E., Mariel, P., Tamanyo, I., Aizpuru, I., \& Zabaleta, A. (2012). Assessing the effect of alternative land uses in the provision of water resources: Evidence and policy implications from southern Europe. Land Use Policy, 29, 761-770. doi:10.1016/j.landusepol.2011.12.001.

Grig, N. S. (1996). Water resources management: Principles, regulations, and cases. New York: McGraw-Hill.

Halimatusadiah, S., Dharmawan, A., \& Mardiana, R. (2012). Efektivitas kelembagaan partisipatoris di hulu daerah aliran Sungai Citarum. Jurnal Sosiologi Pedesaan, 6(1), 71-90.

Juwana, I., Muttil, N., \& Perera, B. J. C. (2012). Indicator-based water sustainability assessment - A Review. Science of the Total Environment, 438, 357-371. doi:10.1016/j.scitotenv.2012.08.093.

Kodoatie, R., \& Sjarief, R. 2010. Tata ruang air. Yogyakarta: Andi.

Mitchell, B. (2005). Integrated water resource management, institutional arrangements, and land-use planning. Environment and Planning A, 37, 1335-1352. doi:10.1068/a37224.

Moss, T. (2004). The governance of land-use in river basins: prospects for overcoming problems of institutional interplay with the EU Water Framework Directive. Land Use Policy, 21(1), 85-94. doi:10.1016/j.landusepol.2003.10.001.

Nielsen, H. O., Frederiksen, P., Saarikoski, H., Rytkonen, A., \& Pedersen, A. B. (2013). How different institutional arrangements promote integrated river basin management. Evidence from The Baltic Sea Region. Land Use Policy, 30(1), 437- 445. doi:10.1016/j.landusepol.2012.04.011.

Pawitan, H., \& Haryani, G. S. (2011). Water resources, sustainability and societal livelihoods in Indonesia. Ecohydrology \& Gydrobiology, 11(3-4), 231-243. doi:10.2478/v10104-011-0050-3.

Presiden Republik Indonesia. (2004). Undang-Undang Republik Indonesia Nomor 7 Tahun 2004 tentang Sumber Daya Air. Indonesia: Sekretaris Negara Republik Indonesia.

Presiden Republik Indonesia. (2004). Undang-Undang Republik Indonesia Nomor 32 Tahun 2004 tentang Otonomi Daerah. Indonesia: Sekretaris Negara Republik Indonesia. 


\section{Efektivitas Kelembagaan Pemerintah dalam Integrasi Pola Pengelolaan Sumber Daya Air ...}

Presiden Republik Indonesia. (2007). Undang-Undang Republik Indonesia Nomor 26 Tahun 2007 tentang Penataan Ruang. Indonesia: Sekretaris Negara Republik Indonesia.

Presiden Republik Indonesia. (2008). Peraturan Pemerintah Republik Indonesia Nomor 42 Tahun 2008 tentang Pengelolaan Sumber Daya Air. Indonesia: Sekretaris Negara Republik Indonesia.

Santoso, B. (2006). Pola pengelolaan sumber daya air di sistem Kedung Ombo: Tinjauan terhadap aspek kelembagaan. Jurnal Teknik Sipil, 3(2), 49-59.

Sugiyono. (2008). Metode penelitian kuantitatif, kualitatif, dan R\&D. Bandung: Alfabeta.

Wiering, M., \& Immink, I. (2006). When water management meets spatial planning: A policy-arrangement perspective. Environmental and Planning C: Politics and Space, 24(3), 423-438. doi:10.1068/c0417j.

Yuwono, S. B., Sinukaban, N., Murtilaksono, K., \& Sanim, B. (2011). Land use planning of Way Betung Watershed for sustainable water resources development of Bandar Lampung City. Journal of Tropical Soils, 16(1), 77-84. doi:10.5400/jts.2011.16.1.77. 